\title{
Information system strategies: The South African context
}

\author{
Neil Duffy \\ Graduate School of Business Administration, University of the Witwatersrand, 2 St. Davids Place, Parktown, \\ Johannesburg 2193, Republic of South Africa
}

Received August 1990

\begin{abstract}
Many studies of information systems (IS) issues place IS strategy at the top of the list. In this article the development is sketched of IS strategy and then the relevant findings are summarised of a number of studies undertaken at the Wits Business School over the last five years which provide the South African context. From these studies it is possible to derive an information systems strategy profile of the respondent organisations and to trace the information systems issues that have concerned them. It is interesting to note that some of these information systems issues seem to have persisted through the years and seem likely to continue to do so.
\end{abstract}

Heelwat navorsingstudies oor inligtingstelselvraagstukke plaas inligtingstelselstrategie bo aan die lys. In hierdie artikel word eers die ontwikkeling van IS-strategie geskets en daarna word die resultate van verskeie navorsingstudies wat gedurende die afgelope vyf jaar by die Wits Sakeskool uitgevoer is, saamgevat. Deur hierdie studies as basis te gebruik, is dit moontlik om 'n profiel van die deelnemende organisasies se inligtingstelselstrategieè op te stel en om die IS-vraagstukke te identifiseer. 'n Belangrike gevolgtrekking is dat van hierdie vraagstukke or die jare heen ontstaan het en waarskynlik in die toekoms steeds sal voorkom.

\section{Introduction}

Most studies of information systems issues place IS strategy at the top of the list. As it is a complex area some background is sketched in this article after which the concept of IS strategy is discussed. Secondly, the importance of the subject is highlighted as well as the South African experience with IS strategy. The article is concluded with a look ahead at probable future issues that will confound the managers who have to deliver IS plans.

\section{Background and evolution}

Planning and control have always been regarded as key management functions. Even before the beginning of the twentieth century, businesses ran on a mixture of policies and procedures which evolved through the early 1900 s into management by objectives, budgeting and project planning. The emphasis at this stage was largely on control with short term planning horizons at best. It was historical control at its most basic. What were the targets? What was actually accomplished? What were the variances? What action was required? Mounting capital investments brought about long range planning which attempted to look much further ahead but was essentially extrapolative in nature with little effort to forecast future business environments. More dynamic business environments highlighted the fallacy of assuming that the future would continue to be more of the same and the result, in about 1955, was strategic planning. Then came strategic management in the mid-seventies. Although strategic management is a complex pastime, Figure 1 gives one view of what it is all about.

While all this was happening the engine of the information age, the computer, emerged into the world of business in the early 1960 s. It rapidly made its mark in the, now, traditional data processing applications of general accounting, stock control, wages and salaries, costing, accounts receivable and sales reporting. In terms of Nolan's (1977) stages of growth business computing technology was probably in the initiation stage in the early 1960s and in the contagion stage in the late $1960 \mathrm{~s}$. By the early 1970s management was attempting to exercise greater control over expenditure on computers and data processing entered the budgeting era. This meant that at that point in time, management was about half a century behind its normal practices when it came to managing DP! In the late 1970s two major events occurred: the personal computer (PC) was born and the strategic potential of computers was recognised. The PC brought managers and information technology (IT) together and the realisation that computers could play a major role in business strategy moved us into the information age, DP became IT and IT took a giant leap forward into the strategic management arena.

This is admittedly a somewhat simplistic version of what actually happened but it succeeds in highlighting the important events and providing the background for the purpose in hand, namely, to review the South African experience in information systems strategy.

\section{The concept of Information systems strategy}

Since IS strategy is a relatively new concept in management terms and, since consensus is still emerging as to its true meaning, it would be advisable to offer a definition of some sort. In broad terms IS strategy is the set of decisions made on the direction information systems are to take to support the strategic thrust of an organisation. To be more specific one can identify the main components of an IS strategy as in Figure 2.

Some forward looking organisations today have a vision that encompasses the following:

- Executive workstations that are really 'tools of the mind' to borrow Steve Job's analogy.

- Universal electronic links between staff and to customers, suppliers, bankers and information sources no matter where in the world they are.

- Information systems that provide reliable transaction processing for all business operations, support strategic thrusts and deliver competitive advantage.

- The ability to rapidly deliver new information systems to anticipate the changing needs of the business. 


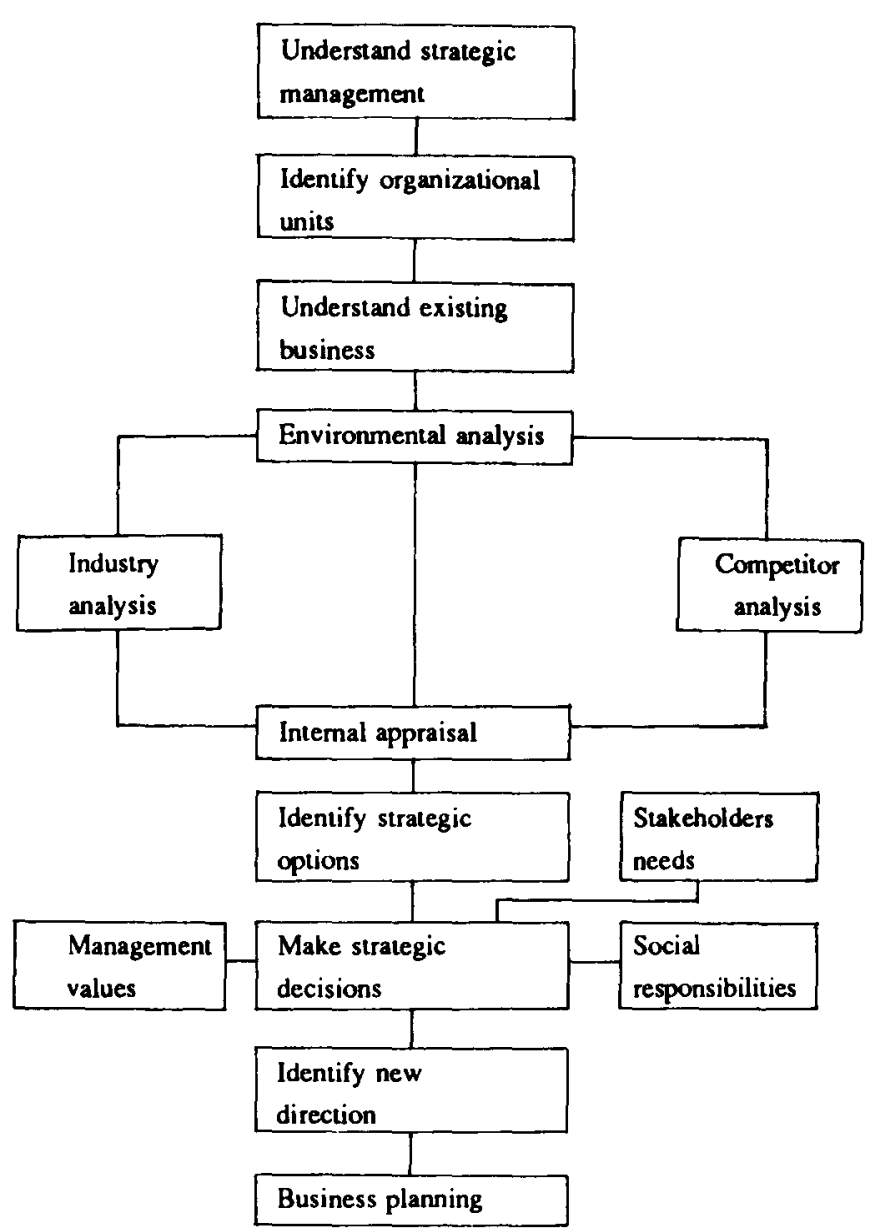

Source: Duffy \& Assad (1989: 76)

Figure 1 The strategic management process

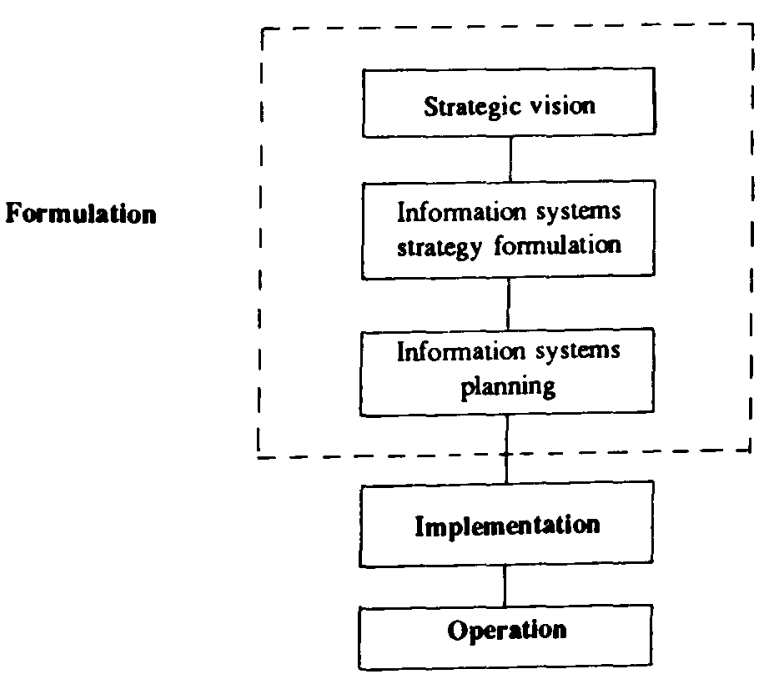

Source: Duffy \& Assad (1989: 91)

Figure 2 Information systems strategy

- All of this focussed on providing newer, more costeffective and better products and services faster to meet changing customer needs within more demanding environmental and stakeholder constraints.

The identification of the people, technology platform, key

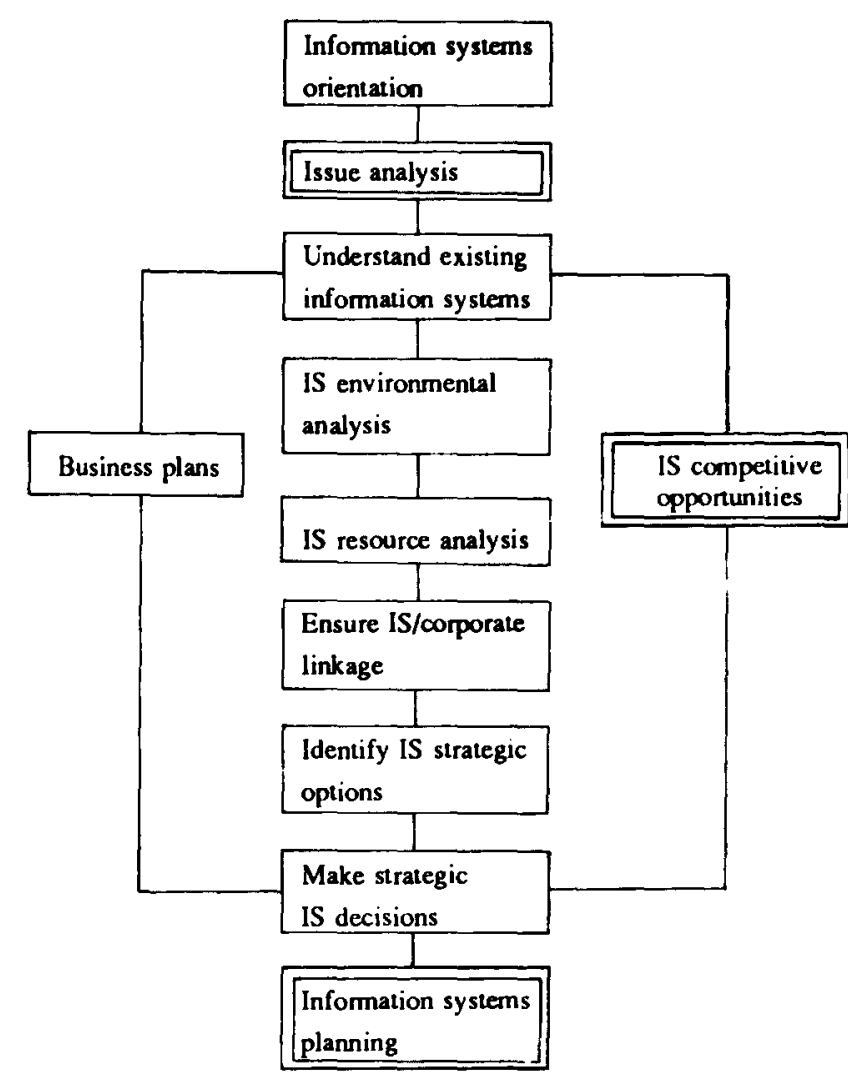

Source: Duffy \& Assad (1989: 92)

Figure 3 The IS strategy formulation process

applications and development priorities can be considered to be the IS strategy formulation. The activities required to make this happen comprise the IS plan. The next level of detail in the IS strategy formulation process is shown in Figure 3.

A good IS plan will contain:

- the organisation structure both within and outside IS to give effect to it;

- what applications are to be developed over the planning period, in what order, by what date, by whom, and under whose responsibility;

- what hardware, software or methodologies will be required when, to develop the planned applications;

- the IS and other people who will be required to develop the systems in the planned time frame;

- the financial implications of the IS plan;

- policy statements on key issues such as security and control, change management, evaluation mechanisms and system flexibility; and

- an action programme to make it all happen.

In general usage the term 'IS strategy' also includes IS planning.

\section{Importance of Information systems strategy}

A number of studies have been done on information system issues (for example Brancheau and Wetherbe [1987] and Herbert and Hartog [1986]. In these and other studies, dating back to 1980 , strategic planning (IS) is rated by 
general and IS management as the number one issue. In some of the more recent studies competitive advantage comes in at number two. There is no doubt, therefore, that IS strategy is a key topic.

The reasons for this are not hard to find. In Western Europe total IS expenditure averaged $2,3 \%$ of gross national product (Computer Weekly, 1986: 24-25). For South Africa a similar percentage would imply an IS expenditure of R3 billion on the gross national product of R133 billion for 1986 (Moore, 1987: 7).

This is confirmed and updated through market research conducted by Business and Marketing Intelligence (Computing SA, 1990: 1). BMI estimated IS revenues to be R5,4 billion for 1990. Of this, software and professional services would be $R 1,28$ billion and hardware sales $R 2,76$ billion.

Additional reasons are to be found in the perceived strategic importance of IT and, in particular, its potential as a competitive weapon.

\section{Information systems strategy in South Africa}

So what can one say about IS strategy in South Africa? In order to answer this question some of the IS strategy research done at the Wits Business School from 1984 until 1989 is reviewed below. Since the strategic role of IS was emerging in the early 1980 s this is the crucial period. We will trace the research chronologically, picking out relevant events and trends, and then attempt to pull it all together at the end.

\section{Goulden (1984)}

The study by Ian Goulden was undertaken when the ideas of the strategic impact of IS (McFarlan and McKenney, 1983), competitive strategy (Porter, 1980), the use of IS for competitive advantage (McFarlan, McKenney and Pyburn, 1983) and critical success factors (Rockart, 1979) were starting to take root.

Warren McFarlan had visited South Africa and many leading edge organisations were attempting to apply the new thinking. Goulden did 12 in-depth interviews with the IS manager and senior executives of seven leading organisations in the banking, insurance, retailing, wholesaling, manufacturing and manufacturing/distribution industries. The relevant findings are set out in Table 1 . All 12 interviewees were familiar with the 'new thinking'. All seven organisations had used IT for competitive advantage with moderate effect (2) or significant effect (5). All regarded IT as an important component of the business effort to remain competitive. In the formulation of business strategy, the IS function was considered to be supportive by two organisations and strategic by five. As far as the strategic grid (McFarlan and McKenney, 1983: 15) is concerned the organisations viewed their positions at that stage as:

$\begin{array}{ll}\text { Strategic } & 3 \\ \text { Tumaround } & 2 \\ \text { Split strategic and tumaround } & 1 \\ \text { Support } & 1\end{array}$

They considered, however, that their positions on the grid should be:
Strategic 5

Split strategic and turnaround 1

Split support and strategic

All respondents were making use of computers (mainframes and microcomputers), communication networks, word processing, data base management systems, and fourth generation languages. Different planning methodologies and procedures were employed in the different companies.

The striking thing about these findings is the level of sophistication of these South African organisations even in the early years of the 'new thinking'. This is noteworthy despite the fact that the organisations were leading edge in terms of IS. There was a high degree of awareness of the importance of IT to their businesses due possibly to competitive pressures and actions. Indeed some of these organisations had already made use of IT as a competitive weapon and this was a 1984 study.

\section{Aspoas (1985)}

The next relevant Wits Business School (WBS) study was completed in 1985 by Janet Aspoas and here the focus was on the insurance industry. She interviewed IS and other managers in six life insurance and four short term insurance companies which together comprised the bulk of their two industries in terms of premium income.

If we look first at the strategic grid we find the following:

Life insurance companies:

- two in the strategic box

- three in turnaround moving into strategic

- one in the factory box

Short term insurance companies:

Table 1 IS strategy findings

\begin{tabular}{|c|c|}
\hline & $\begin{array}{l}\text { Respondents } \\
\qquad(n=7)\end{array}$ \\
\hline Corporate strategy formally documented & 5 \\
\hline Includes specific section for IT. & 4 \\
\hline IS strategy formally documented & 6 \\
\hline \multicolumn{2}{|l|}{ Mechanism to communicate business strategy to } \\
\hline \multicolumn{2}{|l|}{ IS function includes: } \\
\hline Distribution of (parts of) strategy document & 4 \\
\hline Specific communications & 3 \\
\hline IS represented on steering committee & 3 \\
\hline IS represented on executive committee & 4 \\
\hline IS strategy considered/incorporated in corporate strategy & 4 \\
\hline IS strategy is set in line with corporate strategy & 7 \\
\hline Role of IT recognised as requiring senior executive attention & 7 \\
\hline \multicolumn{2}{|l|}{ Criteria for selecting IS/TT projects } \\
\hline Cost reduction & 6 \\
\hline Retum on investment & 1 \\
\hline Product differentiation & 3 \\
\hline Gain/hold market share & 5 \\
\hline Improve customer service & 7 \\
\hline Improve management information & 5 \\
\hline Source: Goulden (1984) & \\
\hline
\end{tabular}


- three in the factory box

- one in the support box

Seven companies had written IS plans: Four used BSP while three had inhouse methodologies. Integration of IS and corporate plans was identified as advanced in four of the life companies and one of the short term insurers and moderate in one of the life companies and three of the short term insurers.

A number of IS strategic issues were identified by the respondents:

- Staff constraints

- Time constraints

- Lack of knowledge of business direction and requirements

- Lack of commitment to planning

- Lack of experience in IS planning

- Uncertainty about the future of IT

- Managing large scale projects

- Staying on top of the field

- Staff shortages

Then to conclude the findings they identified the following CSFs for IS strategy:

- Service

- Communication with users

- Human resource development (the most critical)

Except for the short term insurers, the sophistication of IS strategy which emerged in the previous study is maintained here.

\section{O'Donoghue (1986)}

The two 1986 studies focussed on the use of IT for competitive advantage. The first, by O'Donoghue, looked at nine organisations from a wide range of industries from highly sophisticated multinationals to a traditional one man operation, all of whom had at least one competitive advantage system in place. The major findings are set out in Table 2 .

It is clear that the use of IT for competitive advantage had well and truly arrived by 1986 . The other important observation is the confirmation of the key role of IT in corporate strategy.

Lewis (1986)

Richard Lewis interviewed five MIS executives and six retail merchandising executives from the five biggest retail groups which, collectively, accounted for $70 \%$ of grocery turnover in South Africa. All were classified as being either in the strategic box or in turnaround moving towards strategic on the strategic grid.

Reference to Table 3 shows the impact of IT on the major retail supermarketeers. Perhaps the most interesting finding is that IT had radically altered the relationship between the major chains and their suppliers by making available to them sales information that had previously had to come from the suppliers. IT had also made possible some significant new customer services which, in turn, had impacted the relationship between the chains and their customers.
Table 2 The use of IT for competitive advantage

\begin{tabular}{|c|c|}
\hline & $\begin{array}{l}\text { Respondents } \\
\text { (n=9) }\end{array}$ \\
\hline \multicolumn{2}{|c|}{ What was the main thrust behind developing the system? } \\
\hline Intemal efficiency & 7 \\
\hline Differentiation of service & 2 \\
\hline \multicolumn{2}{|c|}{ Where did the main thrust come from? } \\
\hline Top management & 5 \\
\hline Marketing & 3 \\
\hline Production & $\mathbf{0}$ \\
\hline IS & 1 \\
\hline \multicolumn{2}{|c|}{ Has this system produced identifiable benefits? } \\
\hline Yes & 9 \\
\hline No & $\mathbf{0}$ \\
\hline \multicolumn{2}{|l|}{ Are these benefits quantifiable? } \\
\hline Yes & 2 \\
\hline Parly & 2 \\
\hline Very difficult to quantify & 5 \\
\hline \multicolumn{2}{|c|}{ Has this system had an impact on your competitive position? } \\
\hline Yes & 8 \\
\hline No & 1 \\
\hline \multicolumn{2}{|c|}{$\begin{array}{l}\text { Are the benefits what you expected when the system was } \\
\text { approved? }\end{array}$} \\
\hline More than expected & 3 \\
\hline What was expected & 4 \\
\hline Not as much as expected & 2 \\
\hline \multicolumn{2}{|c|}{$\begin{array}{l}\text { Would you say there are any problems specific to developing } \\
\text { a system for competitive advantage? }\end{array}$} \\
\hline Yes & $\mathbf{0}$ \\
\hline No & 9 \\
\hline \multicolumn{2}{|c|}{ Has integration proved difficult? } \\
\hline Yes & $\mathbf{0}$ \\
\hline No & 9 \\
\hline \multicolumn{2}{|c|}{$\begin{array}{l}\text { How imponant a role do you think IT will play in deter- } \\
\text { mining your competitive position in the future? }\end{array}$} \\
\hline Not important & 0 \\
\hline Of some importance & 0 \\
\hline Very important & 9 \\
\hline \multicolumn{2}{|c|}{$\begin{array}{l}\text { How much importance is amached to IT planning when } \\
\text { developing the company's strategic plan? }\end{array}$} \\
\hline Limle & 2 \\
\hline Some & $\mathbf{0}$ \\
\hline Major & 7 \\
\hline \multicolumn{2}{|c|}{$\begin{array}{l}\text { Do you see the nature of the CEO's involvement with IT } \\
\text { planning increasing? }\end{array}$} \\
\hline No & $\mathbf{0}$ \\
\hline Yes & 4 \\
\hline Already very high & 5 \\
\hline Source: O'Donoghue (1986) & \\
\hline
\end{tabular}

Walters (1987)

Walters looked at six top companies and six of the largest companies from the 1987 Financial Mail Top Companies Survey as well as six Government departments. Table 4 summarises the major findings.

From Table 4 it seems that the larger organisations planned more formally than the other two groups, had slightly 
Table 3 The impact of IT in supermarket retailing

\begin{tabular}{|c|c|}
\hline & $\begin{array}{l}\text { Respondents } \\
\quad(n=11)\end{array}$ \\
\hline \multicolumn{2}{|c|}{ IT's contribution to the achievement of corporate strategy } \\
\hline \multicolumn{2}{|l|}{ objectives } \\
\hline Reduction of operating costs & 11 \\
\hline \multicolumn{2}{|c|}{ Introduction of new consurner services } \\
\hline Insignificant & 3 \\
\hline Significant & 8 \\
\hline \multicolumn{2}{|c|}{ Penetration of new consumer market segments } \\
\hline Insignificant & 7 \\
\hline Significant & 4 \\
\hline \multicolumn{2}{|c|}{$\begin{array}{l}\text { The effect of IT on the supermarketers' relationship with } \\
\text { important groups in their industry }\end{array}$} \\
\hline \multicolumn{2}{|l|}{ Suppliers } \\
\hline None & 0 \\
\hline Some & $\mathbf{0}$ \\
\hline Significant & 11 \\
\hline \multicolumn{2}{|l|}{ Customers } \\
\hline None & 2 \\
\hline Some & 5 \\
\hline Significant & 4 \\
\hline \multicolumn{2}{|l|}{ Competitors } \\
\hline None & 0 \\
\hline Some & 6 \\
\hline Significant & 5 \\
\hline Source: Lewis (1986) & \\
\hline
\end{tabular}

longer planning horizons, and received the corporate plan in more cases. The majority of the companies claimed to produce formal IS plans but linkage of the IS plans to the corporate plans was limited.

Moore (1987)

Moore studied 18 IS projects in seven medium and large organisations. He interviewed one senior manager per organisation and two users and two IS staff per project making a total of about 60 interviewees. The main concem of his research was IS implementation. From the literature he identified 69 success variables. These were classified into:

State variables

- Management

- Users

- IS function

Process variables

- Integration (management)

- Change (users)

- Innovation (IS)

Moore's research showed that these are indeed valid success variables for the implementation of IS strategy.

\section{Szigeti (1989)}

The most recent study quoted here is that of Laszlo Szigeti (1989) which included 14 medium to large organisations from various industries. In terms of location on the strategic grid they looked like this:
Table 4 IS planning practices

\begin{tabular}{lllll}
\hline Question & Answer & $\begin{array}{c}\text { Top } \\
\text { companies }\end{array}$ & $\begin{array}{c}\text { Largest } \\
\text { companies }\end{array}$ & $\begin{array}{c}\text { Government } \\
\text { departments }\end{array}$ \\
\hline Receive corporate plan? & Yes & 2 & 5 & 1 \\
& No & 4 & 1 & 5 \\
Prepare written IS plan? & Yes & 4 & 6 & 3 \\
& No & 2 & 0 & 3 \\
Are the two plans linked? & Yes & 1 & 3 & 1 \\
& No & 1 & 2 & 0 \\
& No answer & 4 & 1 & 5 \\
Time span of the IS plan? Average & 3 & 4 & 3 \\
Source Walters (1987) & & & & \\
\hline
\end{tabular}

Strategic 7

Tumaround 0

Factory 3

Support 3

The relevant findings from this research are summarised in Table 5.

In addition to the above, the following IS strategic planning issues were identified:

- Lack of knowledge of business direction and requirements

— Lack of skilled IS staff

- Time constraints

- Uncertainty about the future of technology

- No formal business plan

- Cost of technology

\section{IS strategy profile}

Szigeti's recent research shows a typical IS strategy profile for an organisation that looks like this:

- Located in the strategic or turnaround box of the strategic grid

- Formal, written IS plans

- An IS planning horizon of three to five years

- A fair degree of integration between corporate and IS strategies

- A high level of importance attached to the IS plan by senior management and a fair amount of involvement by them in the IS planning process

- IS planning done annually

- A formal planning process that has been in place for more than three years

- A planning methodology that is either informal, home grown or an adaptation of a commercial methodology

A remarkable consistency exists on many of these points between the Szigeti and earlier studies. Although all the studies were based on small samples this consistency between them lends credibility to the findings.

Szigeti did not address the question of strategic applications of IT but these were more than adequately covered by O'Donoghue and Lewis in their 1986 studies. It is clear that IT has been used strategically, and for competitive advantage, in South Africa since before 1984 when Goulden carried out his research. 


\section{IS strategy issues}

It is also noteworthy that the strategic IS issues raised first by Aspoas in 1985 are very similar to those identified by

Table 5 Approaches to IS planning

\begin{tabular}{|c|c|}
\hline & $\begin{array}{l}\text { Respondents } \\
(n=13)\end{array}$ \\
\hline \multicolumn{2}{|l|}{ Who is responsible for IS planning? } \\
\hline The senior IS manager & 3 \\
\hline The senior IS manager plus other IS managers & 4 \\
\hline The MIS planning department & 6 \\
\hline \multicolumn{2}{|l|}{ How is planning accomplished? } \\
\hline Primarily through informal face-to-face discussions & 2 \\
\hline $\begin{array}{l}\text { Primarily through formal presentations, meetings etc. } \\
\text { Primarily through the interpretation of writuen }\end{array}$ & 9 \\
\hline business plans & 2 \\
\hline \multicolumn{2}{|l|}{ How is top management involved? } \\
\hline Through ad hoc formal discussion & 1 \\
\hline Through a series of formal presentations & 6 \\
\hline Primarily to review and approve the wriuen MIS plan & 6 \\
\hline \multicolumn{2}{|l|}{ Importance of the written IS plan to decision making } \\
\hline Low & 2 \\
\hline Moderate & 3 \\
\hline High & 8 \\
\hline \multicolumn{2}{|l|}{ Status of IS manager } \\
\hline High & 4 \\
\hline Moderate & 9 \\
\hline Low & 0 \\
\hline \multicolumn{2}{|l|}{ What importance does top management attach to the } \\
\hline \multicolumn{2}{|l|}{ IS strategic plan? } \\
\hline Low & 1 \\
\hline Moderate & 3 \\
\hline High & 9 \\
\hline \multicolumn{2}{|l|}{$\begin{array}{l}\text { If accepted, what level of commitment is there from manage- } \\
\text { ment in general? }\end{array}$} \\
\hline Low & 1 \\
\hline Moderate & 7 \\
\hline High & 5 \\
\hline \multicolumn{2}{|l|}{ Does a formal, written IS plan exist? } \\
\hline Yes & 11 \\
\hline No & 1 \\
\hline Parly & 1 \\
\hline \multicolumn{2}{|l|}{ How often is it drawn up? } \\
\hline Annually & 10 \\
\hline Bi-annually & 1 \\
\hline \multicolumn{2}{|l|}{ How long has the process been in place? } \\
\hline Less than three years & 3 \\
\hline Three years & 4 \\
\hline More than three years & 5 \\
\hline \multicolumn{2}{|l|}{ What is the planning horizon? } \\
\hline Less than three years & 2 \\
\hline Three to five years & 9 \\
\hline More than five years & 1 \\
\hline \multicolumn{2}{|l|}{ What use is made of formal IS planning methodologies? } \\
\hline Own & 5 \\
\hline Modified commercial methodology & 3 \\
\hline No formal approach & 6 \\
\hline Source: Szigeti (1989) & \\
\hline
\end{tabular}

Szigeti in 1989 which, in tum, are similar to those identified in the Price Waterhouse studies of 1988/89 and 1990. It seems as if many core IS strategy issues are intractible (see Table 6).

It seems a safe bet that the intractible IS strategic issues will be with us for some years yet. They include:

- Cost containment

- Integrating IT and corporate strategy

- Predicting future technology

- Meeting project deadlines

- Staff shortages

- Lack of funds

- Integrating IT in an age of networking

There seems little doubt that the political and economic forces in South Africa will continue to drive a number of the issues that have been identified above, namely cost containment (due to inflation), lack of funds, staff shortages and IT integration (data communications infrastructure).

\section{Conclusion}

The question of IS strategy is a complex one. It was, therefore, necessary to spend time on the concept before addressing the main theme of the paper which is the South African experience in IS strategy. A review of seven local studies revealed that some South African organisations are surprisingly sophisticated when it comes to IS strategy. This level of sophistication was not easily achieved. Many difficult IS strategy issues have plagued our managers in the past and will continue to do so in the future. Amongst these are the South African political and economic situations which provide additional unique problems.

\section{References}

Aspoas, J. 1985. The perceived importance of information system strategic planning in the insurance industry. Johannesburg: Unpublished research report in the Graduate School of Business Administration, University of the Witwatersrand. Brancheau, J.C. \& Wetherbe, J.C. 1987. Key issues in information systems management, MIS Quarterly, March, $23-46$.

Table 6 Information system strategy issues (1985-1990)

\begin{tabular}{lcccc}
\hline Issues & $\begin{array}{c}\text { Aspoas } \\
1985\end{array}$ & $\begin{array}{c}\text { PWI } \\
88 / 89\end{array}$ & $\begin{array}{c}\text { Szigeti } \\
1989\end{array}$ & $\begin{array}{c}\text { PWSA } \\
1990\end{array}$ \\
\hline Linking IT and corporate strategy & $\mathbf{x}$ & $\mathbf{x}$ & $\mathbf{x}$ & $\mathbf{x}$ \\
Cost containment & & $\mathbf{x}$ & $\mathbf{x}$ & $\mathbf{x}$ \\
Lack of control & & & & $\mathbf{x}$ \\
Meeting project deadlines & $\mathbf{x}$ & $\mathbf{x}$ & & $\mathbf{x}$ \\
Staff retention & $\mathbf{x}$ & & & $\mathbf{x}$ \\
Predicting future technology & $\mathbf{x}$ & $\mathbf{x}$ & $\mathbf{x}$ & $\mathbf{x}$ \\
Staff recruitment & $\mathbf{x}$ & & $\mathbf{x}$ & $\mathbf{x}$ \\
Integrating communications and DP & & & & $\mathbf{x}$ \\
Maintenance of programs & & $\mathbf{x}$ & & $\mathbf{x}$ \\
Lack of commitment to IS planning & $\mathbf{x}$ & & & \\
Lack of experience with IS planning & $\mathbf{x}$ & & & \\
Keeping up with IT developments & $\mathbf{x}$ & & & \\
Time constraints & $\mathbf{x}$ & & $\mathbf{x}$ & \\
\hline
\end{tabular}


Computer Weekly. 1986. League of big spenders, IDC DP expenditure survey, Computer Weekly, 4 December. 24-25.

Computing SA. 1990. BMI predicts $16 \%$ growth, Computing SA. 20 August, 1.

Duffy, N.M. \& Assad, M.G. 1989. Information management: Strategy formulation and implementation. Cape Town: Oxford University Press, 540p.

Goulden, 1.H. 1984. The impact of information technology on corporate strategy in selected organisations. Johannesburg: Unpublished research report in the Graduate School of Business Administration, University of the Witwatersrand.

Herbert, M. \& Hartog. C. 1986. MIS rates the issues, Datamation, November 15, 79-86.

Lewis, R.G. 1986. The effectiveness of information technology as a competitive weapon in mass merchandise supermarket retailing. Johannesburg: Unpublished research report in the Graduate School of Business Administration, University of the Witwatersrand.

McFarlan, F.W. \& McKenney, J.L. 1983. Corporale information systems management: The issues facing senior executives. Homewood, Illinois: Richard D. Irwin.

McFarlan, F.W., McKenney, J.L. \& Pyburn, P. 1983. Information Archipelago: Charting the course. Harvard Bus. Rev., January-February.

Moore, M.V. 1987. Implementing successful information systems: An exploratory study. Johannesburg: Unpublished research report in the Graduate School of Business Administration,
University of the Witwatersrand.

Nolan, R.L. 1978. Restructuring the data processing organization for data resource management. B. Gilchrist (Ed.), Information Processing 1977, Amsterdam: North Holland Publishing Company, 261-265.

O'Donoghue, T.E. 1986. The application of information technology as a competitive weapon in selected companies. Johannesburg: Unpublished research report in the Graduate School of Business Administration, University of the Witwatersrand.

Price Waterhouse. 1989. Managing information technology: International survey - 1988/89. London: Price Waterhouse, 22p.

Porter, M.E. 1980. Competitive stralegy. New York: The Free Press.

Price Waterhouse. 1990. Managing information technology: Soush African survey - 1990. Johannesburg: Price Waterhouse.

Rockart, J.F. 1979. Chief executives define their own data needs. Harvard Bus. Rev., March-April, 81-91.

Szigeti, L. 1989. Information systems strategic planning in selected organisations. Johannesburg: Unpublished research report in the Graduate School of Business Administration, University of the Witwatersrand.

Walters, J.B. 1987. The effectiveness of information resource management in selected South African organizations. Johannesburg: Unpublished research report in the Graduate School of Business Administration, University of the Witwatersrand. 